\title{
The growth and yield of hybrid maize on shaded agroecosystem
}

\author{
Sodiq Jauhari, R. Heru Praptana*, Samijan, and Meinarti Norma Setiapermas \\ Assessment Institute for Agricultural Technology of Central Java, Jalan. Soekarno-Hatta KM 26 No. \\ 10 Bergas, Kab. Semarang, Jawa Tengah 50552
}

\begin{abstract}
The development of maize in shade areas is one of the efforts to increase the national maize production. The study objective was to determine the growth and yield adaptation of hybrid maize in shaded areas. The study was conducted in the sengon forest area of Kalices Village, Patehan District, Kendal Regency from March to September 2020. The study was designed using a randomized block design with split-split plots with treatments including: a) shade density $(0 \%, 20 \%$ and $40 \%)$ as the main plot; b) cultivation technology (PTT and existing farmers) as subplots; and c) varieties (JH 37, Nasa 29 and Bisi 18) as sub-plots. Each treatment was replicated 3 times in order to obtain 18 treatment combinations and each replication was planted in a plot with a size of 350 $\mathrm{m}^{2}$. The parameters observed included the percentage of plants growing, plant height at harvest, age $50 \%$ male flowers, age $50 \%$ female flowers, cob height, cob length, cob weight, cob diameter, number of rows per cob, number of seeds per row, weight of dry seeds, seed moisture content, yield per plot and yield per hectare. The data were processed by analysis of variance and if there is a significant difference, it was further tested with DMRT at the 5\% level. The results showed that the shading had a very significant effect on most of the yield components, namely cob length, number of seed rows per cob, wet and dry shell weight per 10 cobs, wet stubble weight per 10 plants, wet stubble weight, and dry shell weight. However, there is no significant effect on the growth components of growth power, cob circumference and cob position. The growth and yield adaptation of maize was better at $20 \%$ shade density compared to $40 \%$ shade density. On land with a shade density of $20 \%$, the highest productivity was obtained in the Bisi 18 of 5.9 t/ha with a potential yield of $62.7 \%$, followed by Nasa 29 of $5.8 \mathrm{t} /$ ha with a potential yield of $58.41 \%$, and $\mathrm{JH} 37$ as much as $5.2 \mathrm{t} / \mathrm{ha}$ with a potential yield of $25 \%$.
\end{abstract}

\section{Introduction}

Maize is an agricultural commodity that has an important role in the national economy and can be a source of foreign exchange through the export market. Maize is one of the main secondary crops in Indonesia, both as food and feed [1], and has great potential and opportunities to be utilized in the perspective of economic development, food security and

* Corresponding author: herujuly@yahoo.com 
energy security [2]. The need for maize for food, feed, and industrial raw materials continues to increase. The average need for maize for consumption in 2018 reached 23.25 million tons with a production target of 29.93 million tons, resulting in a surplus of 6.68 million tons [3]. In 2019, maize production reached 27.8, and in 2020 it increased to 28.63 million tons [4].

Efforts to increase production and productivity of maize continue to be carried out in line with the reduction of land and the advancement of location-specific maize cultivation technology innovations, for a sustainable supply of maize. Maize development is directed at dry land agroecosystems such as the use of community forest areas. Central Java is the second national maize center after East Java [5; 6]. Development of agricultural areas on dry land in Central Java covering an area of $\pm 955,587$ ha with a maize production target in 2021 of 3.69 million tons [7].

Maize development in Central Java is mostly done on dry land. In Grobogan Regency, maize is grown on dry land at the beginning of the rainy season and the beginning of the dry season [8]. Maize farming on dry land in Wonosobo Regency is profitable and efficient [9]. The development of maize cultivation areas on dry land is predicted to increase the GRDP of the agricultural sector by $5.94 \%$ (10].

Dry land for maize development in a number of areas in Central Java is land under stands such as stands of teak, sengon, rubber, coconut, and eucalyptus. Planting maize as an intercrop among plantation crops is often done by farmers to utilize the available land, especially on immature staple crops [11]. The extent of control of the sengon forest by farmers in Central Java has the potential to expand the maize development area. The land between the sengon forest area is identical to shade stress, so it is necessary to innovate shade-stress tolerant maize technology. In exploring the potential of dry land in each region, it is necessary to select a technology package that is in accordance with site-specific conditions [12].

The main problem with maize cultivation in dry land is that water requirements are completely dependent on rainfall, variations in soil fertility, reduced soil fertility due to erosion [8], and shade stress on land under stands. Currently, there are many varieties of hybrid maize that can be used as references for farmers, but not much is known about their adaptability and production if they are developed in dry land agroecosystems under shade stress. The aim of the study was to determine the adaptation to growth and yield of hybrid maize in shaded areas.

\section{Materials and method}

The rescobch was conducted in the community forest land of Kalices Village, Patean District, Kendal Regency, from March to September 2020. The rescobch area used is a sengon forest area of $20,000 \mathrm{~m}^{2}$ (2 ha). Prior to the rescobch, the characteristics of the rescobch location were observed.

The study was carried out using a split-split plot randomized design with shade treatment $(0 \%, 20 \%$ and $40 \%)$ as the main plot, fertilizer (integrated crop management = PTT and farmer pattern) as subplots, and varieties (JH 37, Nasa 29 and Bisi $18=$ farmer's existing hybrid maize) as sub-plots. Each treatment was repeated 3 times so that there were 18 treatment combinations. The sub-plot plots are $350 \mathrm{~m} 2$ in size and the distance between the sub-plots is $1.0 \mathrm{~m}$.

Planting using a system without tillage (TOT) with a spacing of $75 \mathrm{~cm}$ x $40 \mathrm{~cm}(2$ seeds/hole). After planting, the planting hole is covered with drum fertilizer. The seeds used had a germination rate of $>95 \%$. Planting was carried out one week before planting time for farmers around the research area. Plant maintenance includes: 1) weed control with herbicides and concomitant planting; 2) pest prevention and control; 3) periodic monitoring 
of pest and disease attacks; and 4) irrigation according to the needs and environmental conditions of the plantation. Hybrid maize cultivation techniques with PTT and farmer patterns are shown in detail in Table 1.

Table 1. Hybrid maize cultivation techniques with PTT and farmer patterns

\begin{tabular}{|c|c|c|c|}
\hline \multirow{2}{*}{ No } & \multirow{2}{*}{ Component } & \multicolumn{2}{|c|}{ Cultivation Technique } \\
\hline & & PTT & Farmer Pattern \\
\hline 1 & Varieties & JH 37, Nasa 29 & Bisi 18 \\
\hline 2 & Seed quality & Certified & Certified \\
\hline 3 & Seed treatment & Metalaksil (Ridomil) & - \\
\hline 4 & Planting distance & $75 \mathrm{~cm} \mathrm{x} 40 \mathrm{~cm}$ & $75 \mathrm{~cm} \times 40 \mathrm{~cm}$ \\
\hline 5 & Number of seeds per hole & 2 seeds & 2 seeds \\
\hline 6 & Land cultivation & Without tillage & Without tillage \\
\hline 7 & Chemical fertilizer & $\begin{array}{l}\text { Urea } 200 \mathrm{~kg} / \mathrm{ha} \text { and NPK } 350 \\
\mathrm{~kg} / \mathrm{ha}\end{array}$ & $\begin{array}{l}300 \mathrm{~kg} / \mathrm{ha} \text { and NPK } 500 \\
\mathrm{~kg} / \mathrm{ha}\end{array}$ \\
\hline 8 & $\begin{array}{l}\text { Chemical fertilizer } \\
\text { application }\end{array}$ & $\begin{array}{l}\text { Twice: } 7-10 \text { days after } \\
\text { planting = DAP }(1 / 3 \text { Urea) and } \\
30 \text { DAP ( } 2 / 3 \text { Urea); pit } 5-7 \mathrm{~cm} \\
\text { from plant }\end{array}$ & $\begin{array}{l}\text { Dua kali 7-10 DAP and 30- } \\
35 \text { DAP; pit 5-7 } \mathrm{cm} \text { from } \\
\text { plant }\end{array}$ \\
\hline 9 & Organic fertilizer & Compost Petroganik & Cow dung \\
\hline 10 & Irrigation & $\begin{array}{l}\text { Watering at the beginning of } \\
\text { growth, the vegetative phase, } \\
\text { the flowering phase, and the } \\
\text { cob formation phase }\end{array}$ & $\begin{array}{l}\text { No irrigation schedule } \\
\text { setting }\end{array}$ \\
\hline 11 & Weeding & $\begin{array}{l}\text { Herbicides before planting and } \\
\text { mechanically together with } \\
\text { soiling }\end{array}$ & $\begin{array}{l}\text { Herbicides before planting } \\
\text { and mechanically together } \\
\text { with soiling }\end{array}$ \\
\hline 12 & Pest control & $\begin{array}{l}\text { Observation of pests on a } \\
\text { regular basis, especially the } \\
\text { control of pests in the } \\
\text { vegetative phase }\end{array}$ & Pesticide \\
\hline
\end{tabular}

Parameters observed were the percentage of growing plants, plant height at harvest, cob height, length of the cob, circumference of the cob, weight of the cob, number of rows/cob, number of rows of seeds/cob, weight of wet shells, weight of dry shells, and weight of wet stover. Wet shelled weight and dry shelled weight were measured from 10 sample cobs from each sub-plot. The weight of wet stover was measured from 10 sample plants and the total weight of tiled plants (number of plants in an area of $2.5 \mathrm{~m} \times 2.5 \mathrm{~m}$ ). The data were analyzed using analysis of variance and if the F-count showed a significant difference, then proceed with the Duncen multiple range test (DMRT) at the 5\% level [13].

\section{Results and discussion}

\subsection{Growth performance and yield components}

The results of statistical analysis of growth data and yield components showed that shade and variety treatments had a significant effect on several growth parameters and yield components, while fertilizer treatment significantly affected one yield component, namely dry shell weight. The interaction between shade treatment and fertilizer resulted in a significant difference in the number of rows of seeds/cobs, the interaction between shade treatment and varieties resulted in a significant difference in wet shell weight, the interaction between fertilizer and variety treatments resulted in a significant difference in 
plant height and cob circumference, and the interaction between treatments shade, fertilizer and variety resulted in significant differences in cob circumference and wet stover weight (Table 2).

Table 2. Results of analysis of variance of treatment effects and interactions between treatments on growth performance and yield components of hybrid maize.

\begin{tabular}{|c|c|c|c|c|c|c|c|}
\hline Parameter & $\begin{array}{l}\text { Shade } \\
(\mathbf{N})\end{array}$ & $\begin{array}{l}\text { Fertilizer } \\
\text { (P) }\end{array}$ & $\begin{array}{l}\text { Variety } \\
\text { (V) }\end{array}$ & $\begin{array}{c}\mathbf{N} \mathbf{x} \\
\mathbf{P}\end{array}$ & $\begin{array}{c}\mathbf{N} \mathbf{x} \\
\mathbf{V}\end{array}$ & $\begin{array}{c}\mathbf{P x} \\
\mathbf{V}\end{array}$ & $\begin{array}{l}\mathbf{N} \times \mathbf{P} \\
\times \mathbf{V}\end{array}$ \\
\hline $\begin{array}{l}\text { Percentage of growing } \\
\text { plants }(\%)\end{array}$ & tn & tn & $* *$ & tn & tn & tn & tn \\
\hline Plant height $(\mathrm{cm})$ & tn & tn & ** & tn & tn & ** & $\operatorname{tn}$ \\
\hline Cob height $(\mathrm{cm})$ & ** & tn & tn & tn & tn & tn & tn \\
\hline $\begin{array}{l}\text { Circumference of the cob } \\
(\mathrm{cm})\end{array}$ & tn & tn & tn & tn & tn & ** & ** \\
\hline Length of the $\operatorname{cob}(\mathrm{cm})$ & ** & tn & $* *$ & tn & tn & tn & $\operatorname{tn}$ \\
\hline number of rows/cob & ** & tn & tn & ** & tn & tn & tn \\
\hline Weight of wet shells $(\mathrm{kg})$ & ** & tn & ** & tn & ** & tn & tn \\
\hline Weight of dry shells (kg) & ** & tn & ** & tn & tn & tn & tn \\
\hline Weight of dry shells (t/ha) & ** & *** & ** & tn & tn & tn & tn \\
\hline Weight of wet stover $(\mathrm{kg})$ & ** & tn & tn & tn & tn & tn & ** \\
\hline $\begin{array}{l}\text { Weight of wet stover tiles } \\
(\mathrm{kg})\end{array}$ & $* *$ & tn & $* *$ & tn & tn & tn & th \\
\hline
\end{tabular}

Description: $\mathrm{tn}=$ not significantly different; $* *=$ significantly different at level $=0.05$

Shade is related to the amount of light intensity. The degree of variation in light intensity is highly dependent on the surrounding canopy structure, especially within the dense canopy structure typical of mature plant stands [14]. Light directly affects plant growth and yield potential [15]. Light is directly related to the process of photosynthesis. Light distribution is an important factor affecting maize photosynthesis [16]. The results of rescobch by [17], showed that light intensity had an effect on plant height, number of leaves, leaf width-length ratio, plant dry weight and root-tooth ratio of maize plants. Several maize varieties grown under the shade of oil palm aged 12 ycobs showed significant differences in plant height, amount of chlorophyll a and $b$, number of leaves, leaf length, leaf area, segment length, weight of cob without skin, dry cob weight, and seed weight. dry per hectare [18]. Coconut tree shade also significantly affected plant height, number of rows per cob, weight of 1000 seeds, and production per hectare of composite and hybrid maize [19].

The results of the study by [20] showed that variety had a significant effect on plant height, leaf area, root fresh weight, cob weight, cob weight, but had no effect on cob diameter and shoot fresh weight. The best interaction between varieties and biological fertilizers is shown in the yield component of cob weight without maize husks [21]. Plant height, number of cobs, and length of maize cobs were significantly affected by $\mathrm{N}$ fertilizer treatment and plant population density [22]. Rescobch by [23] also showed that the interaction between varieties and $\mathrm{N}$ fertilizer significantly affected the number of seeds per cob, weight of 1000 seeds and weight of seeds per ha.

\subsection{The effect of shade on the weight of the maize stove}

The results showed that the interaction between shade and variety had a significant effect on the fresh weight of maize plants. Table 3 shows that there is consistency in the weight of each variety. The higher the percentage of shade, the lower the weight of the pods for both the PTT pattern and the farmers. The difference is seen in the highest achievement of wet 
weight in each shade level. The highest weight of wet pods in open land was obtained on the Nasa 29 variety with farmer-pattern fertilization. In the $20 \%$ shade treatment, the highest weight of wet pods was obtained in Bisi 18 variety with farmer pattern fertilization. In the $40 \%$ shade treatment, the highest weight of wet pods was obtained in the Nasa 29 variety with PTT fertilization. Meanwhile, the lowest bean weight was consistently obtained in the JH 37 variety with PTT fertilization.

Table 3. The average tile weight of three varieties of hybrid maize in three shade treatments and two fertilizations.

\begin{tabular}{|c|l|c|c|c|}
\hline \multirow{2}{*}{ Shade } & \multirow{2}{*}{ Fertilizer } & \multicolumn{3}{|c|}{ Variety } \\
\cline { 3 - 5 } & & JH 37 & Nasa 29 & Bisi 18 \\
\hline \multirow{2}{*}{$0 \%$} & PTT & $7.5 \mathrm{bcde}$ & $8.9 \mathrm{abcd}$ & $11.4 \mathrm{ba}$ \\
\cline { 2 - 5 } & Farmer Pattern & $7.7 \mathrm{bcde}$ & $12.8 \mathrm{a}$ & $10.2 \mathrm{abc}$ \\
\hline \multirow{2}{*}{$20 \%$} & PTT & $5.1 \mathrm{cde}$ & $7.0 \mathrm{bcd}$ & $5.4 \mathrm{cde}$ \\
\cline { 2 - 5 } & Farmer Pattern & $5.5 \mathrm{cde}$ & $6.4 \mathrm{cde}$ & $8.1 \mathrm{abcde}$ \\
\hline \multirow{2}{*}{$40 \%$} & PTT & $3.2^{\mathrm{e}}$ & $5.4 \mathrm{cde}$ & $4.1 \mathrm{ed}$ \\
\cline { 2 - 5 } & Farmer Pattern & $4.0 \mathrm{ed}$ & $3.3 \mathrm{e}$ & $3.9 \mathrm{ed}$ \\
\hline
\end{tabular}

Note: The numbers followed by different letters mean that they are significantly different at the DMRT test level of 0.05

The difference in the wet weight gain that varies between varieties is thought to be due to differences in the genetic expression of each variety under different shade stresses and different nutrient availability conditions. The yield of wet bean pods is influenced by the interaction of the growing environment, application of fertilizers and varieties. Space weight is used to determine the assimilation of photosynthate produced by a plant. [24] stated that the height and weight of fresh bean curd is determined by the rate of photosynthesis which is the accumulation of photosynthate during growth.

\subsection{The effect of shade on the weight of dry pillars and weights}

Table 4 shows that the higher the shade density, both with PTT fertilization and farmer patterns, the lower the yield. Based on the results obtained, it can be seen that there is a consistency in the highest and lowest yields of each variety in the treatment of farmer patterns, namely Bisi 18 and JH 37. While in the PTT fertilization treatment, the highest yields were in $0 \%$ shade (open land) and 20\% shade (medium). obtained in the Bisi 18 variety and the lowest was in the JH 37 variety, while in the shade $40 \%$ (weight) the highest yield was obtained in the Nasa 29 variety and the lowest was in the $\mathrm{JH} 37$ variety. Based on the average yield, that in the $40 \%$ shade there was a decrease in yield ranging from 38,5 $63.5 \%$ (3.7-6.1 t/ha dry shelled seeds).

Table 4. The average weight of dry shelled seeds of three hybrid maize varieties in three shade treatments and cultivation techniques.

\begin{tabular}{|c|l|c|c|c|}
\hline \multirow{2}{*}{ Shade } & \multirow{2}{*}{ Fertilizer } & \multicolumn{3}{|c|}{ Variety } \\
\cline { 3 - 5 } & & JH 37 & Nasa 29 & Bisi 18 \\
\hline \multirow{2}{*}{$0 \%$} & PTT & $6.5 \mathrm{bc}$ & $8.7 \mathrm{ba}$ & $9.6 \mathrm{a}$ \\
\cline { 2 - 5 } & Farmer Pattern & $6.3 \mathrm{bc}$ & $8.5 \mathrm{ba}$ & $8.6 \mathrm{ba}$ \\
\hline \multirow{2}{*}{$20 \%$} & PTT & $5.2 \mathrm{cde}$ & $5.3 \mathrm{cde}$ & $5.9 \mathrm{de}$ \\
\cline { 2 - 5 } & Farmer Pattern & $3.4^{\mathrm{e}}$ & $5.8 \mathrm{de}$ & $5.3 \mathrm{cde}$ \\
\hline \multirow{2}{*}{$40 \%$} & PTT & $3.1^{\mathrm{e}}$ & $3.9 \mathrm{de}$ & $3.5 \mathrm{de}$ \\
\cline { 2 - 5 } & Farmer Pattern & $2.9^{\mathrm{e}}$ & $3.2 \mathrm{e}$ & $3.4^{\mathrm{e}}$ \\
\hline
\end{tabular}

Note: The numbers followed by different letters mean that they are significantly different at the 0.05 DMRT test level 
The dry shell yield of Bisi 18 variety in open land with a dose of PTT fertilizer was 9.6 $\mathrm{t} / \mathrm{ha}$, exceeding the average yield in the variety description, which was $9.1 \mathrm{t} / \mathrm{ha}$. Meanwhile, the dry shell yield of the Nasa 29 and JH 37 varieties was still below the average yield in the variety description, which were $11.9 \mathrm{t} / \mathrm{ha}$ and $10.7 \mathrm{t} / \mathrm{ha}$, respectively. The dry shell yield of the three varieties was seen to be lower on land with denser shade. In the Nasa 29 variety there was a decrease in dry shelled yield of 39-55.1\% (3.4-4.8 t/ha), and in the JH 37 variety there was a decrease in yield of $20-52.3 \%$ (1.3-3.4 t/ha). However, the yield of the three varieties was still higher than the results of [25] study, that maize planted under coconut stands with $55.8 \%$ light intensity produced $1.7 \mathrm{t} / \mathrm{ha}$ and maize planted in the open produced $2,8 \mathrm{t} / \mathrm{ha}$. The yield of dry shelled C3 hybrid maize planted under deep coconut with $35.1 \%$ irradiation for three consecutive ycobs was $1.2 \mathrm{t} / \mathrm{ha}$ in the first ycob, $0.8 \mathrm{t} / \mathrm{ha}$ in the second ycob, and in the third ycob of $2.6 \mathrm{t} / \mathrm{ha}[26]$.

Observations showed that the yield on open land was higher than that obtained from shaded land. Sengon plants that are more than 2 ycobs old already have a canopy that has begun to close and reduces the light that reaches the land surface by about $40-50 \%$. Maize plants grown under $50 \%$ shade will experience a yield reduction of up to $60 \%[27 ; 28]$. When compared between dry shelled yields on open land and $20 \%$ shaded land with PTT fertilization, the highest yield difference was obtained by Bisi 18 variety of $4.3 \mathrm{t} / \mathrm{ha}$ with a potential yield of $44.8 \%$, followed by Nasa 29 variety of $3.4 \mathrm{t} /$ ha with a yield potential of $39.1 \%$ and the $\mathrm{JH} 37$ variety $3.1 \mathrm{t} / \mathrm{ha}$ with a yield potential of $47.7 \%$. This difference indicates an increase in yield with the interaction between shade level and variety. Utilization of intercropped land under sengon stands should only be carried out until sengon plants are 2-2.5 ycobs old with a plant population of $60 \%$ from monoculture systems [29].

\section{Conclusion}

The shading had a very significant effect on most of the yield components, namely cob length, number of seed rows per cob, wet and dry shell weight per 10 cobs, wet stubble weight per 10 plants, wet stubble weight, and dry shell weight. However, there is no significant effect on the growth components of growth power, cob circumference and cob position. The growth and yield adaptation of maize was better at $20 \%$ shade density compared to $40 \%$ shade density. On land with a shade density of $20 \%$, the highest productivity was achieved by the Bisi 18 variety with a yield potential of $5.9 \mathrm{t} / \mathrm{ha}$ with a potential yield of $62.7 \%$, followed by Nasa 29 with a potential yield of $5.8 \mathrm{t} / \mathrm{ha}$. $58.41 \%$, and JH 37 as much as 5.2 t/ha dry shelled with a potential yield opportunity of $25 \%$.

\section{References}

1. Sarasutha, I.G.P. 2002. Kinerja usahatani dan pemasaran jagungdi sentra produksi. Jurnal Litbang Pertanian 21(2):38-47.

2. Bantacut, T., M.T. Akbar, Y.R. Firdaus. 2015. Pengembangan jagung untuk ketahanan pangan, industri dan ekonomi maize development for food security, industry and economy. PANGAN 24(2): 135-148.

3. Kementrian Pertanian RI, 2018. Dukungan Litbang Pertanian, Meningkatkan Produksi Komoditas Pangan. Kementerian Pertanian, di Jakarta, Rabu (4/1/2017).

4. Pusdatin Kementerian Pertanian RI. 2016. Outlook Komoditas Pertanian Tanaman Pangan Jagung. 86 Hal.

5. L.M. Aini, 2019. Penentuan provinsi-provinsi terbaik dalam produksi jagung nasional melalui analisis kuadran atas variable produksi dan produktivitas per satuan luas lahan. Jurnal Ekonomi Pertanian dan Agribisnis (JEPA) 3(4): 751-760. 
6. T.Hastini, I. Noviana. 2020. Kinerja Teknologi Budidaya Jagung Hibrida di Indonesia. AGROTROP 10 (2): 123 -141.

7. Distanbun Jateng, 2018. Rencana Strategis Tahun 2018-2013. Dinas Pertanian dan Perkebunan Provinsi Jawa Tengah. 161 hal.

8. M.Sulistyoningsih, 2002. Pengembangan Tanaman Jagung pada Agroekosistem Lahan Kering sebagai Sumberdaya Pakan Ternak di Kabupaten Grobogan (Bentuk Intercroping Jagung dan Kedelai). Majalah Ilmiah LONTAR 16(2): 25-37.

9. Rahayu, W., U. Barokah, R.U. Fajarningsih. 2020. Strategi pengembangan usahatani jagung pada lahan kering di Kabupaten Wonosobo. AGRISEP 19(1): 207-218.

10. Harimurti, E.F., K. Munibah, U. Sudadi. 2018. Pengembangan Kawasan Budidaya Jagung Untuk Peningkatan Perekonomian Kabupaten Pemalang. TATA LOKA 20(3): 215-231

11. Mahdiannoor dan N. Istiqomah. 2015. Pertumbuhan dan hasil dua varietas jagung hibrida sebagai tanaman sela dibawah tegakan karet. ZIRAA'AH 40(1): 46-53.

12. S.Minardi, 2009. Optimalisasi Pengelolaan Lahan Kering Untuk Pengembangan Pertanian Tanaman Pangan. Pidato Pengukuhan Guru Besar Ilmu Tanah Pada Fakultas Pertanian Universitas Sebelas Maret Disampaikan dalam Sidang Senat Terbuka Universitas Sebelas Maret Pada tanggal 26 Pebruari 2009. 40 hal.

13. Gomez, A.A. and K.A. Gomez. 1993. Statistical procedures foragricultural rescobch (2nd edition). An International RiceReccobch Institute Book. A Wiley Intersience Publication (JohnWiley and Sons). NY, Chicago, Brisbane, Toronto, Singapura.

14. R.A.Slattery, B.J. Walker, A.P.M. Weber, R. Donald. 2018. The Impacts of Fluctuating Light on Crop Performance. Ort. Plant Physiology 176: 990-1003.

15. Y., Fan, J. Chen, Y. Cheng, M.A. Raza, X. Wu, Z. Wang, Q. Liu, R. Wang, X. Wang, T. Yong, W. Liu, J. Liu, J. Du, K. Shu, W. Yang, F. Yanget. 2018. Effect of shading and light recovery on the growth, leaf structure, and photosynthetic performance of soybean in a maizesoybean relay-strip intercropping system. PLoS ONE 13(5): e0198159. https://doi.org/10.1371/ journal.pone.0198159

16. Liu, T., F. Song, S. Liu and X. Zhu. 2011. Canopy structure, light interception, and photosynthetic characteristics under different narrow-wide planting patterns in maize at silking stage. Spanish Journal of Agricultural Rescobch 9(4): 1249-1261.

17. H.A. Akmalia, E. Suharyanto. 2017. Pengaruh perbedaan intensitas cahaya dan penyiraman pada pertumbuhan jagung (zea mays 1.) 'Sweet Boy-02'. J. Sains Dasar 6(1): $8-16$.

18. Syafrullah, N. Marlina, S.E. Rahim, R.I.S. Aminah, Midranisiah, Rosmiah and F. Sakalena. 2017. Growth and Production of Some Variety Maize (Zea mays L.) Planted under the Canopy of Palm Oil 12 Ycobs Old in Swamp Land. IOP Conf. Series: Materials Science and Engineering 209 (2017) 012109 doi:10.1088/1757899X/209/1/012109.

19. Abdullah, S., R. Neswati and Nasruddin. 2020. Maize-coconut Intercropping System in the Humid Tropics Dry Land of Indonesia. Asian Journal of Plant Sciences 19: 107113.

20. Fahrurrozi, Z. Muktamar, Dwatmadji, N. Setyowati, S. Sudjatmiko, M. Chozin. 2016. Growth and Yield Responses of Three Sweet Maize (Zea mays L. var. Saccharata) Varieties to Local-based Liquid Organic Fertilizer. International Joural on Advanced Science Engineering Information Technology 6(3): 319-323.

21. S. Khairiyah, Khadijah, M. Iqbal, S. Erwan, N. Mahdiannoor. 2017. Pertumbuhan dan hasil tiga varietas jagung manis (Zea mays saccharata Sturt) terhadap berbagai dosis pupuk organik hayati pada lahan rawa lebak. ZIRAA'AH 42(3): 230-240.

22. A. Worku, B. Derebe, Y. Bitew, G. Chakelie and M. Andualem. 2020. Response of maize (Zea mays L.) to nitrogen and planting density in Jabitahinan district, Western 
Amhara region. Cogent Food \& Agriculture 6:1, 1770405, DOI: 10.1080/23311932.2020.1770405

23. S.Ahmad, , A.A. Khan, M. Kamran, I. Ahmad, S. Ali,d S. Fahad. 2018. Response of Maize to Various Nitrogen Levels. European Journal of Experimental Biology 8(1):14.

24. Yulisma. 2011. Pertumbuhan dan Hasil Beberapa Varietas Jagung pada Berbagai Jarak Tanam. Penelitian Pertanian Tanaman Pangan 30(3):196-203.

25. Ruskandi 2003. Prospek usaha tani jagung sebagai tanaman sela di antara tegakan kelapa. Buletin Teknik Pertanian 8(2): 55-59.

26. E. Randriani, E. Wardiana, Y. Ferry, N. Heryana. 1998. Keragaan beberapa tanaman sela diantara kelapa. Prosiding Konferensi Nasional Kelapa, Bandar Lampung. Hal: 266-273.

27. Sopandie D, Trikoesoemaningtyas, E. Sulistyono, N. Heryani. 2002. Pengembangan kedelai sebagai tanaman sela: Fisiologi dan pemuliaan untuk toleransi terhadap naungan. Laporan Penelitian Hibah Bersaing. Jakarta (ID): Dirjen Dikti, Kementerian Pendidikan.

28. Marwoto, A. Wijanarko, Subandi. 2008. Prospek pengusahaan tanaman kedelai di perkebunan karet. p. 280-293. Dalam: Supriadi, M, A.D. Sagala, N. Siagian, T. Kustyanti, A. Rachmawan (eds). Prosiding Lokakarya Nasional Agribisnis Karet, Yogyakarta, 20-21 Agustus 2008. Bogor (ID): Pusat Penelitian Karet.

29. Widiharto A. 2008. Potensi dan implementasi pengusahaan tanaman jagung pada perkebunan karet. p. 273-279. Dalam: Supriadi, M, A.D. Sagala, N. Siagian, T. Kustyanti, A. Rachmawan (eds). Prosiding Lokakarya Nasional Agribisnis Karet, Yogyakarta, 20-21 Agustus 2008. Bogor (ID): Pusat Penelitian Karet. 